\title{
Problems of Condition and Preservation of a Species Chestnut (Castanea satiya Mill.)
}

\author{
Bebya S.M.* \\ Institute of Botany of the Academy of Sciences of Abkhazia, Republic of Abkhazia
}

Submission: December 17, 2018, Published: January 03, 2019

"Corresponding author: Bebya SM, Institute of Botany of the Academy of Sciences of Abkhazia, 384933 Sukhum, Gulia St. 22, Republic of Abkhazia

\section{Abstract}

The state of the Chestnut forests of Western Transcaucasia is characterized. Their unsatisfactory phytosanitary condition is noted. The necessity of further research to rescue the species of Castanea Satiya from extinction throughout the entire area of its distribution is substantiated.

Keywords: Castanea Satiya; Phytosanitary condition; Cryphonectria parasitica; Natural renewal

\section{Introduction}

The Chestnut genus (Castanea Mill.) Includes about 20 species of deciduous trees and shrubs, common in warm and moderately warm regions of the Northern Hemisphere. In the Caucasus, the only Tertiary-relict Southern European-Balkan-Caucasian-Little Asiaian species of this genus naturally grows - Castanea sativa Mill., which plays an important landscape-forming role [1]. The sowing chestnut is one of the largest and valuable forest-forming, fruit-bearing, honey-bearing tree species. Usually it is a tree of the first size, up to $35 \mathrm{~m}$ in height, with a wide rounded crown. On the southern macroslopes of the Western Transcaucasia it grows from the seashore to $1800 \mathrm{~m}$ above sea level. However, vertically, it forms its own forest chestnut belt at elevations from 500 to $1000 \mathrm{~m}$ above sea level. In the upper part of the distribution, in the subalpine belt chestnut grows mainly in the form of shrubs.

Chestnut mesophilic and calcephobic wood. It prefers moist shaded slopes and rather loose deep brown forest soils. Carbonate soil avoids. It grows mainly on the slopes adjacent to the valleys of the major rivers Kodor, Gumista, Bzyb, Mzymta and other rivers. It forms both stands with its domination and mixed with Iberian oak (Quercus iberica Stev.), Caucasian hornbeam (Carpinus caucasica Grossh.), Eastern beech (Fagus orientalis Lipsky) and other species. Pure chestnut stands are extremely rare.

a. The most common types of forest are: Castanetum nudum; Castanetum festucosum with Festuca drymeja Mert. Et Koch; Castanetum trachystemosum with Trachystemon orientalis (L.) G. Don fil. From bush types may be mentioned: Castanetum laurocerasosum with Prunus laurocerasus L., Castanetum luteo rhododendrosum witch Rhododendron lutea Sweet, Castanetum rhododendrosum with Rhododendron ponticum $\mathrm{L}$.
Under natural conditions, chestnut is resumed by seed or by growth, on fires and basal suckers. Among broad-leaved trees, chestnut is one of the best sowing seeds, which is capable of renewing vegetative (coppice, basal suckers) by and forming a highly productive stands.

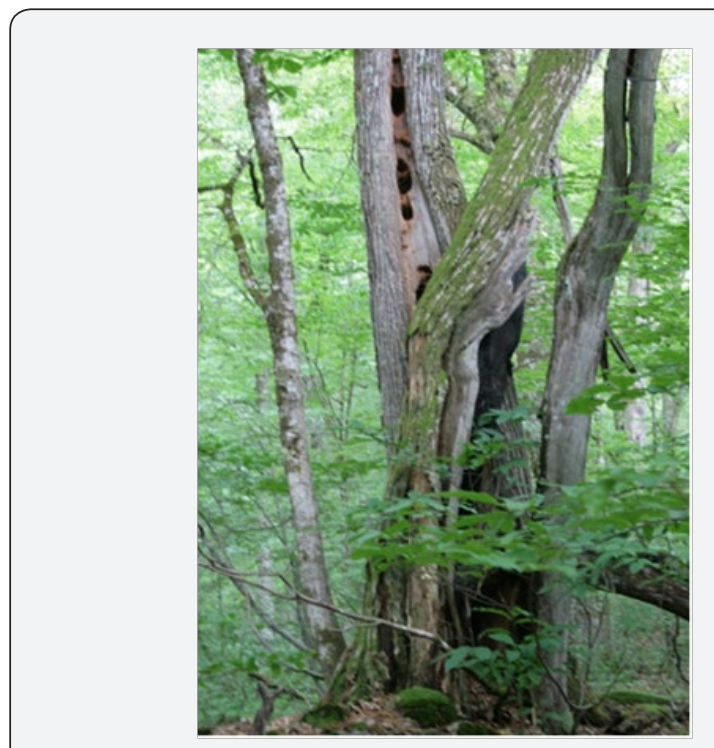

Figure 1: Drying Castanea sativa quantitative and qualitative accounting (tract Sanchar, 2010) of natural renewal.

In the past, chestnut forests in Western Transcaucasia occupied large areas, up to $4.5 \%$ of the total forest area. For many years, the main felling, unauthorized predatory felling, as well as the so-called "sanitary felling" were carried out in these forests. In the forests, intensive grazing of livestock occurs. All these negative anthropogenic factors caused significant damage to the state 
of chestnut forests, significantly worsening their phytosanitary condition. Drying is observed both in individual trees (Figure 1) and in whole areas of chestnut plantations. The leading role in the weakening and death of chestnut stands is played by fungal pathogens Cryphonectria parasitica (Murrill) ME. Barr. [2].

To confirm the above, we give a description of the chestnut plantation on a sample area (trial plot, TP) of 0.2 hectares, which we laid in Tsmursky forest area of Pskhu-Gumistinsky reserve (Abkhazia) in 2018. TP laid in a wet gorge Eastern Gumista river on a slope of up to 450 steepness, at a hypsometric elevation of 725 m, with geographic coordinates: N. - 4308904, E. - 04102438.

Exposure TP south-east. Soils are fined gravelly, powerful. The underlying rock is shale. Growth conditions are ideal for good growth and development of chestnut. On the TP forest taxation, forest typological, forest pathological, sanitary descriptions of plantings.

Live ground cover is developed, covering 90\%. It consists mainly of Festuca drymeja Mert. et Koch), Rubus sp., rarely, there are: Euphorbia sp., Circaea lutetiana L., Polygonatum multiflorum (L.) All., Salvia glutinosa L., Cicerbita bourgaei (Boiss) Beauverd, Campanula longistyla Fom., Trachystemon orientale (L.) D. Don, ferns - Polystichum setiferum (Forssk.) Moore ex Woynar, Pteridium aquilinum Ruhn., Hedera colchica (C. Koch) C. Koch and others.

\section{In the undergrowth}

Vaccinium arctostaphylos L., Hypericum xilosteifolium (Spach.) Robson, Prunus laurocerasus L., Rhododendron luteum Sweet, Epimedium colchicum (Boiss.) Trautv. Type of forest is Castanetum festucosum II class. Bonitet with Festuca drymeja Mert. et Koch.

The stand is mixed and broad-leaved with the dominance of Castanea sativa. In the impurity of the stand one can be found: the Hornbeam Caucasian (Carpinus caucasica Grossh.), Iberian oak (Quercus iberica Stev.), Bearded alder (Alnus barbata C.A. Mey.), Field maple (Acer laetum C.A. Mey).

Average composition of the stand 10Castanea, unit: Carpinus, Alnus, Acer. Closeness of the forest stand 07-08. The stand is uneven, complex, two-tier. The total number of trees at TP is 53, the average height of trees of the first tier is $24 \mathrm{~m}$, the second tier is $16 \mathrm{~m}$. The total timber stock is $27.25 \mathrm{~m} 3$, which in translation per 1 ha is $136 \mathrm{~m} 3$. The area is littered with deadwood. Approximately 15 years ago there was a ground fire, the lower parts of tree trunks are damaged by fire. All trees of the first tier and most of the second dry-tops. All chestnut trees are infected with Cryphonectria parasitica. The sanitary condition of the planting is unsatisfactory.

In quantitative terms, the renewal of the main forest-forming species is satisfactory. The total number of undergrowth up to
$3 \mathrm{~m}$ high is 12 thousand pieces per 1 ha, including 7 thousand chestnuts. However, the undergrowth of chestnut is also infected with $90 \%$ of Cryphonectria parasitica. In general, the life position of the chestnut is greatly weakened and without the implementation of serious measures to rehabilitate the chestnut in the plantation there will be a change of its broad-leaved species, which from a silvicultural point of view and in practical terms is extremely undesirable.

The problem of chestnut is acute in the whole range of its distribution in the Caucasus, in Southern Europe, in the Mediterranean countries [3]. Scientists in many countries have long been involved in this problem. A special program has been created in the UN structures to save this breed. Unfortunately, it is not yet possible to develop effective rescue measures. Of course, research and search for measures to rescue a chestnut from extinction as a relict species must be continued. Putting it on the list of rare and endangered species of regional Red Books is not enough.

Chestnut relic of the tertiary period. Over the millions of years of his existence, undoubtedly survived a lot of natural shocks and survived. Let us hope that there will be natural enemies of Cryphonectria, especially in the upper part of its distribution, where the intensity of the disease is noticeably less, and the species will not disappear. An intelligent person can and should contribute to this. Of course, no types of logging in chestnuts, under any pretext, should not be allowed. In order to preserve and restore chestnut forests, it is necessary to regulate the collateral use of them livestock grazing, collection of food and medicinal plants and other anthropogenic activities that worsen the conditions for chestnut growth.

It is advisable to ensure the natural seed renewal of chestnut, conducting breeding work on the selection in nature and reproduction in cultures of resistant forms of chestnut. Chestnut forest crops can be created in conditions of vegetation, corresponding to its bioecological peculiarities up to the age of 50 years. After 50 years, chestnut fruit crops need to be replaced with new plantings. A sowing chestnut, with the status of an endangered species, is not only necessary to be entered in the regional Red Books, but also provided with appropriate protection.

\section{References}

1. Kolakovsky AA (1982) Flora of Abkhazia. Volume II. Tbilisi. pp. 282.

2. Lukmazova EA (2011) Forest pathology of natural and artificial plantations of chestnut seed in the Republic of Abkhazia. News of the St. Petersburg Forestry Academy, SPb: SPbGLTA (196): 229-237.

3. Tugushi KL (1971) Let's save and restore the chestnut forests of the Caucasus. Forestry 10: 73-77. 
This work is licensed under Creative Commons Attribution 4.0 License DOI: 10.19080/ARTOAJ.2019.19.556090

\section{Your next submission with Juniper Publishers will reach you the below assets}

- Quality Editorial service

- Swift Peer Review

- Reprints availability

- E-prints Service

- Manuscript Podcast for convenient understanding

- Global attainment for your research

- Manuscript accessibility in different formats

( Pdf, E-pub, Full Text, Audio)

- Unceasing customer service

Track the below URL for one-step submission https://juniperpublishers.com/online-submission.php 